\title{
Short communication: Clostridial spore counts in vat milk of Alpine dairies
}

\author{
J. Burtscher, ${ }^{1,2 *}$ (1) L. Hobl, ${ }^{1}$ W. Kneifel, ${ }^{1}$ and K. J. Domig ${ }^{1}(1)$ \\ ${ }^{1}$ Department of Food Science and Technology, University of Natural Resources and Life Sciences Vienna, Vienna 1190, Austria \\ ${ }^{2}$ FFoQSI, Austrian Competence Centre for Feed and Food Quality, Safety and Innovation, Tulln 3430, Austria
}

\begin{abstract}
One of the most severe quality defects in hard and semi-hard cheese, the late blowing defect, is caused by endospore-forming bacteria of the genus Clostridium. To minimize financial losses and waste of resources due to cheese spoilage, raw milk with elevated clostridial spore counts should not be used for the production of certain cheese types. In this context, threshold values of clostridial spore concentrations that cause quality defects in cheese are still under debate. To improve our understanding about late blowing defects, further information on the correlation between clostridial spore concentrations in milk and cheese quality is indispensable. Thus, the aim of this study was to monitor the microbiological quality of milk used for Alpine cheese production regarding clostridial endospore levels to facilitate the establishment of threshold spore concentrations that guarantee the absence of quality defects in Austrian cheese. For this purpose, we monitored clostridial endospore levels in vat milk of 4 Alpine dairies throughout the summer grazing period in 2018. Surprisingly, we observed almost complete absence of butyric acid-producing clostridia in milk and no blowing defects in cheese. Hence, critical clostridial spore concentrations could not be verified. Moreover, the observed low spore levels reveal that the prohibition of silage feeding and good farming practices effectively minimize clostridial endospore counts in milk and ensure the manufacture of high-quality cheese even if technological possibilities are limited.
\end{abstract}

Key words: Clostridium, endospore, Alpine dairy, cheese

\section{Short Communication}

One of the most severe quality defects in hard and semi-hard cheese, the late blowing defect, is caused by endospore-forming bacteria of the genus Clostridium.

Received September 8, 2019.

Accepted November 18, 2019.

*Corresponding author: johanna.burtscher@boku.ac.at
During the ripening process-before microbial growthlimiting salt concentrations in the cheese loaf are achieved and as long as lactate is available as a substrate - clostridial endospores can germinate, transform into vegetative cells, and release undesired metabolites (Brändle et al., 2016). Besides high amounts of carbon dioxide, clostridia produce hydrogen gas, which leads to pronounced textural defects, such as slits, cracks, and irregular cheese eyes. Additionally, excessive amounts of butyric acid cause strong rancid off-flavors. Although the occurrence of late blowing may be relatively rare, its effect is significant. Late blowing usually affects whole batches in cheese production, reduces product value, and causes severe economic losses for cheese producers (Doyle et al., 2015).

To minimize financial losses based on cheese spoilage, raw milk with elevated clostridial spore counts should not be used for the production of certain cheese types. However, it is noteworthy that reported threshold values of spore concentrations that cause quality defects in cheese are highly variable (from 5 to 1,000 spores/L of cheese milk; Dasgupta and Hull, 1989; Stadhouders, 1990; Klijn et al., 1995; Ingham et al., 1998; Jakob, 2005; Ledenbach and Marshall, 2009; Heyndrickx, 2011; Sheehan, 2011). The variation of threshold values partly can be attributed to the plethora of analytical methods used to enumerate clostridia in milk, a fact that has previously been discussed (Brändle et al., 2016, 2017).

Furthermore, it is well known that the extent of late blowing defects depends on the conditions during cheese production and ripening $(\mathrm{pH}$, cooking temperature, salt concentration, size of the cheese loaf, water content, accompanying microbiota, redox potential, and ripening temperature) and accordingly varies among different cheese types (Jakob, 2005; Garde et al., 2011a; Brändle et al., 2016). Quality defects based on clostridial contaminations have been reported, for instance, in Gouda, Edam, Swiss-type cheeses (including Emmental), mountain cheese, Grana Padano, Parmigiano Reggiano, Manchego, and pasta filata cheese (Matteuzzi et al., 1977; Klijn et al., 1995; Cocolin et al., 2004; Le Bourhis et al., 2007; Garde et al., 2011a; 
Bassi et al., 2015; D'Incecco et al., 2015; Bermúdez et al., 2016; Brändle et al., 2018a; Adduci et al., 2019). Protected designation of origin (PDO) cheese types are considered particularly prone to late blowing due to the prohibition of technological measures to eliminate clostridial spores or prevent spore germination and outgrowth (e.g., bactofugation or additives). Even the addition of jenny milk, an effective means to prevent clostridial growth (Cosentino et al., 2015), is prohibited for the production of Austrian PDO cheese. Thus, raw milk used for the production of PDO cheese should undergo some proper monitoring for its endospore levels.

Another aspect that has to be considered is that the published thresholds are often based on practical experience because original research data on the correlation between clostridial spore numbers in milk and cheese quality are scarce. Although various studies have investigated the prevalence of clostridial spores in feces, soil, feed, the stable environment, milk, curd, and cheese, considerably less work has focused on the correlation between milk and cheese quality (Garde et al., 2011a, 2012; Feligini et al., 2014; Bassi et al., 2015; Bermúdez et al., 2016; Driehuis et al., 2016; Turchi et al., 2016; Borreani et al., 2019; Komori et al., 2019; Martin et al., 2019).

Some studies reported the effects of defined clostridial spore suspensions on experimental cheese quality (Le Bourhis et al., 2007; Garde et al., 2011b; GómezTorres et al., 2015; D'Incecco et al., 2018). However, it is well known that findings obtained using experimental food model systems often do not apply in practice. Indeed, the inoculation levels of clostridial spores used in experimental studies were significantly higher $\left(>10^{4}\right.$ spores/L) than the expected levels from practical experience and according to previous studies related to Austrian hard cheese (Brändle et al., 2018a).

To expand our understanding of the late blowing defect, further information on the correlation between milk and cheese quality is indispensable. Thus, the aims of this study were (1) to gain insights into current clostridial contamination levels of vat milk from Alpine dairies and (2) to clarify whether we can establish certain threshold spore concentrations that ensure the prevention of late blowing defects in cheese.

In a recent study, we have shown that even very low amounts of clostridial spores may lead to pronounced blowing defects in Austrian PDO cheese (Brändle et al., 2018a). Hence, we aimed to select an experimental setting that would adequately represent Austrian cheese production as well as enable the observation of naturally occurring low levels of clostridial spores in cheese milk. For this purpose, we collaborated with Alpine dairies, which produce Austrian PDO cheese. In Europe, and particularly in Austria, traditional cheese production often entails the transhumance of cows from permanent farms in the valley to temporary highland farms to exploit Alpine pastures during summer (June to September; Bergamaschi et al., 2016). For traditional manufacturing of Alp or mountain cheese, any preservatives, stabilizers, chemical additives, or genetically engineered rennet are prohibited. Furthermore, the production of these cheese types requires raw milk that is neither heat-treated nor bactofugated or pasteurized (European Commission, 1992). However, the provided guidelines regulate not only the cheese production process but also the management rules for Alpine farms, such as sustainable pasture farming and animal welfare. The prohibition of silage feeding is considered the most relevant measure to avoid clostridial contamination of raw milk (Vissers et al., 2007).

The 4 collaborating dairies represent an association of 13 dairies, which are located in southern Austria at about $1,600 \mathrm{~m}$ above sea level. The herd size of the 4 dairies ranged from 30 to 45 cows of various breeds (mainly Simmental, Brown Swiss, Holstein Friesian, and Pinzgau) each, which were fed through pasture grazing. Three dairies used a fixed indoor milking parlor, whereas dairy D had a mobile milking parlor for outdoor use. Each of the dairies milked twice daily and produced 1 batch of PDO cheese (brine-salted raw milk hard cheese that requires a minimum ripening period of $7 \mathrm{wk}$ ) per day (5 loaves from about $600 \mathrm{~L}$ of milk; European Commission, 2015). Each day, the cheese producer took an aliquot of $30 \mathrm{~mL}$ of cheese vat milk. Three dairies sampled just before the addition of starter culture and rennet, whereas one dairy had already added the starter culture to the evening milk of the previous day. The frozen samples were transported to the laboratory and stored at $-30^{\circ} \mathrm{C}$ until analysis. In total, we received 235 samples: 69 samples from dairy A (collected from June 28 to September 9, 2018), 80 samples from dairy B (collected from June 27 to September 14, 2018), 46 samples from dairy C (collected from June 27 to August 14, 2018), and 40 samples from dairy D (collected from June 27 to August 21, 2018).

We determined clostridial spore numbers in each vat milk sample using the method described by Brändle et al. (2018b). In brief, we performed a most probable number (MPN) approach using a selective medium (AmpMedia 666; SY-Lab, Neupurkersdorf, Austria) in a microtiterplate according to the following pipetting scheme: 32 replicates of $0.32 \mathrm{~mL}, 32$ replicates of 0.16 $\mathrm{mL}$, and 32 replicates of $0.08 \mathrm{~mL}$. After anaerobic incubation at $37^{\circ} \mathrm{C}$ for $48 \mathrm{~h}$, a color change of the culture medium from red to yellow indicated the presence of butyric acid-producing clostridia. A customized reader (AMP-6000 LabImager TR; SY-Lab) detected the color changes in each well, and clostridial spore counts were 
estimated based on the number of positive reactions per dilution using the corresponding software.

Surprisingly, spore counts of almost all samples (n $=229$ ) were below the method's detection limit of 75 spores/L throughout the entire sampling period. Six samples yielded spore counts of 75 spores/L. Of the total samples, we selected about $20 \%(\mathrm{n}=51)$ for further analyses. We randomly chose 4 cavities of each incubated microtiterplate and streaked $0.1 \mathrm{~mL}$ of the incubated milk-medium mixture on reinforced clostridial agar (Merck, Darmstadt, Germany). After anaerobic incubation (in a jar containing a defined gas mixture of $80 \% \mathrm{~N}_{2}, 10 \% \mathrm{CO}_{2}$, and $10 \% \mathrm{H}_{2}$; Don Whitley Scientific, Bingley, UK) at $37^{\circ} \mathrm{C}$ for $5 \mathrm{~d}$, no growth was observed, which coincided with the previously determined absence of clostridia.

Consequently, the obtained results from cheese vat milk raised the question of whether a threshold of $<75$ clostridial spores/L of milk would be enough to prevent blowing defects in cheese. Hence, during the ripening period of $3 \mathrm{mo}$, the cheese produced at the selected Alpine dairies was inspected for blowing defects. However, concurrent with low clostridial spore numbers in milk, one single cheese exhibited only minor quality defects and was chosen for further microbiological analysis.

For the detection of clostridia in cheese, we adapted the MPN procedure described above and used a simplified MPN protocol, in which fewer vials are filled with larger sample volumes. The detailed protocol is published for the first time and therefore provided in Figure 1. By using the specified sample volume, spore numbers from $<3$ to $>110$ spores/g of cheese can be detected. Duplicate analysis of the late blown cheese sample yielded $<3$ clostridial spores/g of cheese.

The advantage of the new approach is the specific enumeration of butyric acid-producing clostridia in a selective growth medium containing an indicator dye. Conversely, conventional MPN protocols rely on a less specific growth medium and the detection of gas production, a property that is not exclusively attributed to clostridia (Brändle et al., 2016, 2017, 2018b). Moreover, the new approach is easy to use, does not require paraffin or agar, and produces less waste than conventional methods that involve glassware.

Undesired slits or cheese eyes in hard cheese also are commonly associated with the presence of propionibacteria or heterofermentative lactobacilli (Sheehan, 2011). Considering this, we performed further microbiological analyses to investigate the presence of these bacteria. For this purpose, we homogenized $10 \mathrm{~g}$ of grated cheese sample with $90 \mathrm{~mL}$ of a sterile sodium citrate solution $(2 \% \mathrm{wt} / \mathrm{vol})$ in a laboratory blender for 2 min. Then, 10-fold serial dilutions of cheese homogenates were prepared using maximum recovery diluent
(LabRobot Products AB, Stenungsund, Sweden). An aliquot of $0.1 \mathrm{~mL}$ was spread in duplicate on the following media: adapted yeast extract lactate agar $[10 \mathrm{~g}$ of yeast extract, $10 \mathrm{~g}$ of casein peptone, $2 \mathrm{~g}$ of sodium pyruvate, $2 \mathrm{~g}$ of glycine, $1.5 \mathrm{~g}$ of sodium chloride, 0.5 $\mathrm{g}$ of Tween 80, $0.25 \mathrm{~g}$ of $\mathrm{K}_{2} \mathrm{HPO}_{4}, 15.75 \mathrm{~mL}$ of sodium lactate $(50 \%)$, and $12 \mathrm{~g}$ of agar-agar] for the detection of propionibacteria and modified De Man, Rogosa and Sharpe agar (MRS-V), supplemented with vancomycin and mannitol for the enumeration of facultative heterofermentative lactobacilli according to Isolini (1990). We counted brown colonies on yeast extract lactate agar after $7 \mathrm{~d}$ of anaerobic incubation at $30^{\circ} \mathrm{C}$ and all colonies on MRS-V after $3 \mathrm{~d}$ of anaerobic incubation at $37^{\circ} \mathrm{C}$. Finally, we randomly selected colonies from the incubated plates, subcultured them, and identified the isolates using a Bruker (Billerica, MA) MALDI Biotyper System (microflex LT) according to the manufacturer's instructions.

We detected high counts of propionibacteria (6.5 $\times 10^{6} \mathrm{cfu} / \mathrm{g}$ of cheese, identified as Propionibacterium freudenreichii ssp. shermanii) as well as heterofermentative lactobacilli $\left(1.0 \times 10^{7} \mathrm{cfu} / \mathrm{g}\right.$ of cheese, identified as Lactobacillus casei or Lactobacillus parabuchneri). These results were in agreement with earlier findings. When propionibacteria exceeded the level of $10^{6} \mathrm{cfu} / \mathrm{g}$ during ripening of Sbrinz cheese, an atypical taste and undesired cracks were observed (Turgay et al., 2018). In addition, gas blowing of cheese has been attributed to growth of salt-tolerant facultative heterofermentative lactobacilli, such as Lactobacillus casei or obligate heterofermentative L. parabuchneri (Sheehan, 2011; Fröhlich-Wyder et al., 2013). Furthermore, it is important to consider that L. parabuchneri represents the main cause of histamine accumulation in hard and semi-hard raw milk cheeses (Berthoud et al., 2017). Hence, from the results of the microbial cheese analysis, we concluded that the quality defects in the analyzed cheese sample were caused by propionibacteria or lactobacilli rather than clostridia.

Although we had expected low clostridial spore levels of clostridia in vat milk of Alpine dairies, the almost complete absence of clostridia in all samples collected between June and September was surprising. To ensure the reliable detection of clostridia by means of the applied method, we simultaneously (meaning that the analyses were performed at the same time using the same lot of medium and incubating the samples in the same anaerobic jar) analyzed raw milk collected by milk tankers in the valley of the same region from conventional milk production (without prohibition of silage feeding). Milk from 22 compartments of the milk tankers was collected on 2 sampling dates (July 26 and August 21) and analyzed using the MPN approach de- 
scribed above. Clostridial spore counts for these milk samples $(\mathrm{n}=45)$ ranged from 150 to 47,900 spores/L of milk (Figure 2). Per incubated sample, 2 reactions that had been determined as positive by the software were selected and the content of the selected well was streaked on reinforced clostridial agar and incubated anaerobically at $37^{\circ} \mathrm{C}$ for 2 to $5 \mathrm{~d}$. Grown colonies were identified using the Bruker MALDI Biotyper System as described above. In 40 out of 45 samples, the presence of butyric acid-producing clostridia was affirmed (68 wells contained $C$. tyrobutyricum, 1 well contained C. sporogenes, and 1 well contained $C$. cadaveris). These findings confirm the suitability of the applied method for the detection of butyric acid-producing clostridia and exemplify the effect of silage feeding and different farm management practices on clostridial spore counts in milk.

We unfortunately were not able to determine a critical clostridial spore concentration practically correlating with detected late blowing defects in Austrian PDO cheese. However, when clostridial spore levels were below or close to the detection limit of 75 spores/L, we did not observe any blowing defects. Interestingly, we gained valuable insights into the current situation

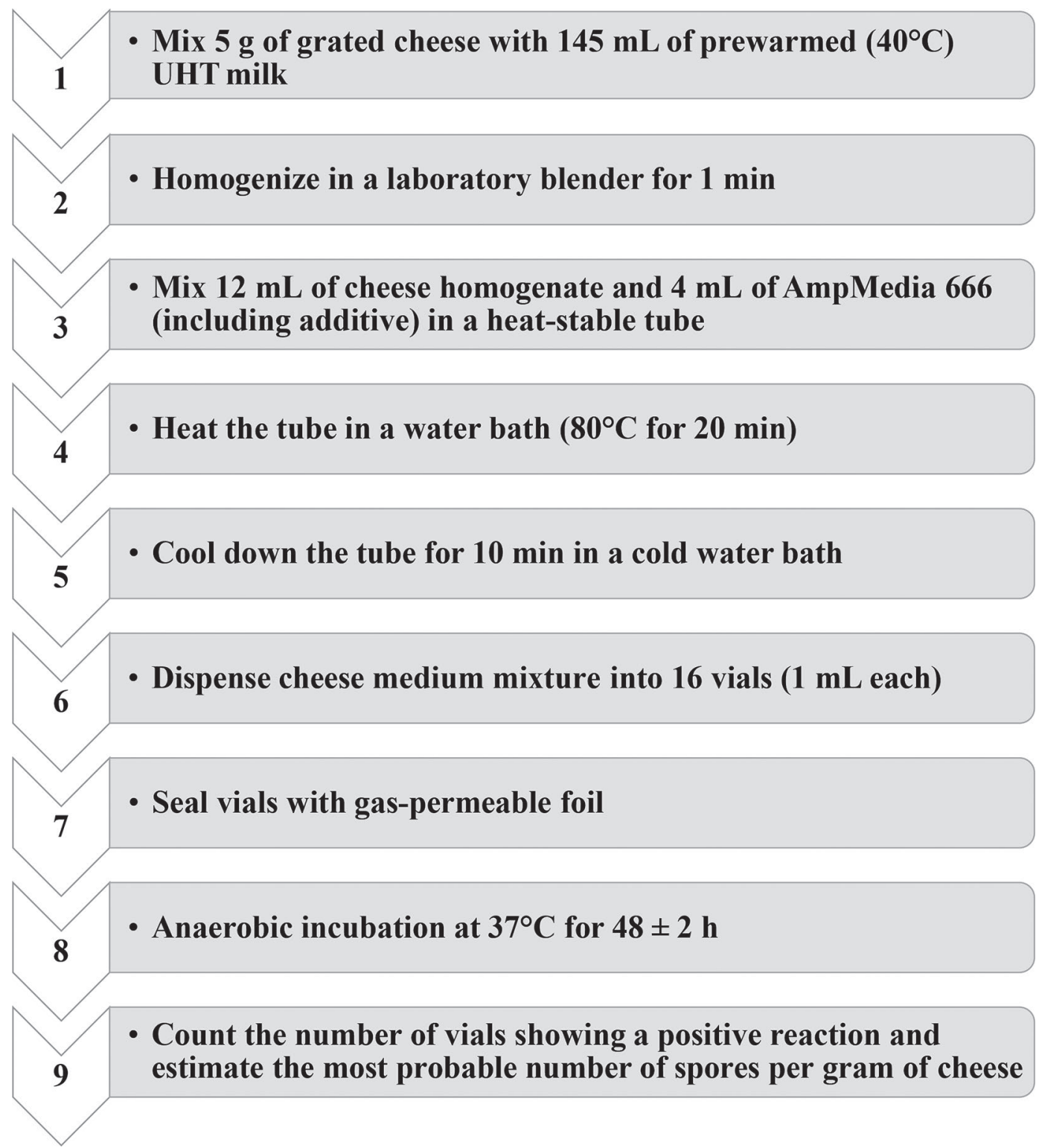

Figure 1. Most probable number (MPN) protocol for the enumeration of clostridial endospores in cheese using AmpMedia 666 (SY-Lab, Neupurkersdorf, Austria). Any color change from red to yellow, even if visible only on the bottom of a vial, has to be registered as a positive reaction. The MPN is calculated according to Hurley and Roscoe (1983). 
related to clostridial contamination levels of vat milk of traditional Alpine cheese producers. We hypothesize that low clostridial spore counts can be explained partly by the exceptionally dry summer $(-22 \%$ rainfall compared with the long-term average) of 2018 (ZAMG, 2018). However, constantly low spore counts throughout the whole season also show that the prohibition of silage feeding and good farming practices effectively contribute to low clostridial endospore concentrations in milk and therefore form an essential part of quality assurance in traditional cheese production. Nevertheless, it should be kept in mind that the onset of late blowing does not depend only on the spore count itself but also on the environmental conditions in cheese allowing spore germination. To the best of our knowledge, this is the first monitoring study that provides an insight into clostridial contamination levels in Alpine milk and cheese, but further studies are encouraged to investigate critical clostridial spore concentrations in cheese milk.

\section{ACKNOWLEDGMENTS}

This work was created within a research project of the Austrian Competence Centre for Feed and Food Quality, Safety and Innovation (FFoQSI; Tulln, Austria). The COMET-K1 competence centre FFoQSI is funded by the Austrian federal ministries of Transport,

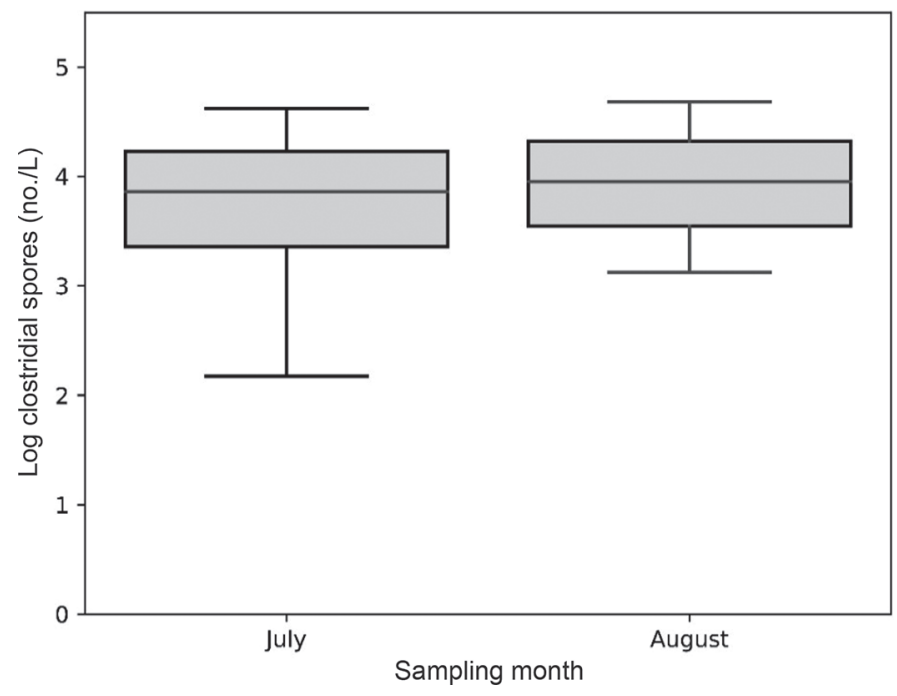

Figure 2. Box and whisker plots of logarithmic clostridial endospore concentrations in milk samples taken from milk tankers that contained milk from dairies located in the valley using silage feeding (July, $\mathrm{n}=22$; August, $\mathrm{n}=23$ ). In the box plot representation, $50 \%$ of data values are within the central box, $25 \%$ are higher (upper whiskers) than the values within the central box, and $25 \%$ are lower (lower whiskers). The horizontal line within the central box represents the median value, whereas the upper and lower boundaries of the whiskers indicate maximum and minimum values.
Innovation and Technology (Vienna) and Digital and Economic Affairs (Vienna), and the Austrian provinces Niederoesterreich, Upper Austria, and Vienna within the scope of COMET - Competence Centers for Excellent Technologies. The program COMET is handled by the Austrian Research Promotion Agency FFG (Vienna). The authors thank the EQ BOKU VIBT GmbH-Center for Preservation and Aseptic Processing (Vienna) for providing the MALDI-TOF MS Bruker (Billerica, MA) Biotyper for bacterial identification. The authors have not stated any conflicts of interest.

\section{REFERENCES}

Adduci, F., H. S. Elshafie, C. Labella, M. Musto, P. Freschi, R. Paolino, M. Ragni, and C. Cosentino. 2019. Abatement of the clostridial load in the teats of lactating cows with lysozyme derived from donkey milk. J. Dairy Sci. 102:6750-6755. https://doi.org/10 $.3168 /$ jds.2019-16311.

Bassi, D., E. Puglisi, and P. S. Cocconcelli. 2015. Understanding the bacterial communities of hard cheese with blowing defect. Food Microbiol. 52:106-118. https://doi.org/10.1016/j.fm.2015.07.004.

Bergamaschi, M., C. Cipolat-Gotet, G. Stocco, C. Valorz, I. Bazzoli, E. Sturaro, M. Ramanzin, and G. Bittante. 2016. Cheesemaking in highland pastures: Milk technological properties, cream, cheese and ricotta yields, milk nutrients recovery, and products composition. J. Dairy Sci. 99:9631-9646. https://doi.org/10.3168/jds.2016 -11199 .

Bermúdez, J., M. J. González, J. A. Olivera, J. A. Burgueño, P. Juliano, E. M. Fox, and S. M. Reginensi. 2016. Seasonal occurrence and molecular diversity of clostridia species spores along cheesemaking streams of 5 commercial dairy plants. J. Dairy Sci. 99:3358-3366. https://doi.org/10.3168/jds.2015-10079.

Berthoud, H., D. Wüthrich, R. Bruggmann, D. Wechsler, M.-T. Fröhlich-Wyder, and S. Irmler. 2017. Development of new methods for the quantitative detection and typing of Lactobacillus parabuchneri in dairy products. Int. Dairy J. 70:65-71. https://doi.org/ 10.1016/j.idairyj.2016.10.005.

Borreani, G., F. Ferrero, D. Nucera, M. Casale, S. Piano, and E. Tabacco. 2019. Dairy farm management practices and the risk of contamination of tank milk from Clostridium spp. and Paenibacillus spp. spores in silage, total mixed ration, dairy cow feces, and raw milk. J. Dairy Sci. 102:8273-8289. https://doi.org/10.3168/ jds.2019-16462.

Brändle, J., K. J. Domig, and W. Kneifel. 2016. Relevance and analysis of butyric acid producing clostridia in milk and cheese. Food Control 67:96-113. https://doi.org/10.1016/j.foodcont.2016.02 .038 .

Brändle, J., V. Fraberger, J. Berta, E. Puglisi, M. Jami, W. Kneifel, and K. J. Domig. 2018a. Butyric acid producing clostridia in cheese - Towards the completion of knowledge by means of an amalgamate of methodologies. Int. Dairy J. 86:86-95. https://doi .org/10.1016/j.idairyj.2018.07.008.

Brändle, J., V. Fraberger, K. Schuller, U. Zitz, W. Kneifel, and K. J. Domig. 2017. A critical assessment of four most probable number procedures for routine enumeration of cheese-damaging clostridia in milk. Int. Dairy J. 73:109-115. https://doi.org/10.1016/j.idairyj .2017.05.011.

Brändle, J., L. Heinzle, V. Fraberger, J. Berta, U. Zitz, M. Schinkinger, W. Stocker, W. Kneifel, and K. J. Domig. 2018b. Novel approach to enumerate clostridial endospores in milk. Food Control 85:318 326. https://doi.org/10.1016/j.foodcont.2017.10.017.

Cocolin, L., N. Innocente, M. Biasutti, and G. Comi. 2004. The late blowing in cheese: A new molecular approach based on PCR and DGGE to study the microbial ecology of the alteration process. Int. J. Food Microbiol. 90:83-91. https://doi.org/10.1016/s0168 $-1605(03) 00296-4$. 
Cosentino, C., R. Paolino, V. Valentini, M. Musto, A. Ricciardi, F. Adduci, C. D'Adamo, G. Pecora, and P. Freschi. 2015. Effect of jenny milk addition on the inhibition of late blowing in semihard cheese. J. Dairy Sci. 98:5133-5142. https://doi.org/10.3168/jds 2015-9458

D'Incecco, P., F. Faoro, T. Silvetti, K. Schrader, and L. Pellegrino. 2015. Mechanisms of Clostridium tyrobutyricum removal through natural creaming of milk: A microscopy study. J. Dairy Sci. 98:5164-5172. https://doi.org/10.3168/jds.2015-9526.

D'Incecco, P., L. Pellegrino, J. A. Hogenboom, P. S. Cocconcelli, and D. Bassi. 2018. The late blowing defect of hard cheeses: Behaviour of cells and spores of Clostridium tyrobutyricum throughout the cheese manufacturing and ripening. Food Sci. Technol. Leb. 87:134-141. https://doi.org/10.1016/j.lwt.2017.08.083.

Dasgupta, A. P., and R. R. Hull. 1989. Late blowing of Swiss cheese: Incidence of Clostridium tyrobutyricum in manufacturing milk. Aust. J. Dairy Technol. 44:82-87.

Doyle, C. J., D. Gleeson, K. Jordan, T. P. Beresford, R. P. Ross, G. F. Fitzgerald, and P. D. Cotter. 2015. Anaerobic sporeformers and their significance with respect to milk and dairy products. Int. J. Food Microbiol. 197:77-87. https://doi.org/10.1016/j.ijfoodmicro 2014.12.022

Driehuis, F., J. Hoolwerf, and J. L. W. Rademaker. 2016. Concurrence of spores of Clostridium tyrobutyricum, Clostridium beijerinckii and Paenibacillus polymyxa in silage, dairy cow faeces and raw milk. Int. Dairy J. 63:70-77. https://doi.org/10.1016/j.idairyj 2016.08.004.

European Commission. 1992. Vorarlberger Bergkäse g.U. Annex I Council Regulation (EEC) No. 2081/92. Accessed Jun. 7, 2019. http://ec.europa.eu/agriculture/quality/door/registeredName html?denominationId $=777$.

European Commission. 2015. AT/PDO/0017/1425. Accessed Oct. 13, 2019. https://ec.europa.eu/agriculture/quality/door/ registeredName.html? denominationId $=321$.

Feligini, M., E. Brambati, S. Panelli, M. Ghitti, R. Sacchi, E. Capelli, and C. Bonacina. 2014. One-year investigation of Clostridium spp. occurrence in raw milk and curd of Grana Padano cheese by the automated ribosomal intergenic spacer analysis. Food Control 42:71-77. https://doi.org/10.1016/j.foodcont.2014.02.002.

Fröhlich-Wyder, M. T., D. Guggisberg, R. Badertscher, D. Wechsler, A. Wittwer, and S. Irmler. 2013. The effect of Lactobacillus buchneri and Lactobacillus parabuchneri on the eye formation of semihard cheese. Int. Dairy J. 33:120-128. https://doi.org/10.1016/j .idairyj.2013.03.004

Garde, S., R. Arias, P. Gaya, and M. Nuñez. 2011a. Occurrence of Clostridium spp. in ovine milk and Manchego cheese with late blowing defect: Identification and characterization of isolates. Int. Dairy J. 21:272-278. https://doi.org/10.1016/j.idairyj.2010.11 .003 .

Garde, S., M. Ávila, R. Arias, P. Gaya, and M. Nuñez. 2011b. Outgrowth inhibition of Clostridium beijerinckii spores by a bacteriocin-producing lactic culture in ovine milk cheese. Int. J. Food Microbiol. 150:59-65. https://doi.org/10.1016/j.ijfoodmicro.2011 .07 .018 .

Garde, S., P. Gaya, R. Arias, and M. Nuñez. 2012. Enhanced PFGE protocol to study the genomic diversity of Clostridium spp. isolated from Manchego cheeses with late blowing defect. Food Control 28:392-399. https://doi.org/10.1016/j.foodcont.2012.05.024.

Gómez-Torres, N., S. Garde, A. Peirotén, and M. Ávila. 2015. Impact of Clostridium spp. on cheese characteristics: Microbiology, color, formation of volatile compounds and off-flavors. Food Control 56:186-194. https://doi.org/10.1016/j.foodcont.2015.03.025.

Heyndrickx, M. 2011. The importance of endospore-forming bacteria originating from soil for contamination of industrial food processing. Appl. Environ. Soil Sci. 2011:1-11. https://doi.org/10.1155/ $2011 / 561975$.

Hurley, M. A., and M. E. Roscoe. 1983. Automated statistical analysis of microbial enumeration by dilution series. J. Appl. Bacteriol. 55:159-164. https://doi.org/10.1111/j.1365-2672.1983.tb02660.x.
Ingham, S. C., J. R. Hassler, Y. W. Tsai, and B. H. Ingham. 1998. Differentiation of lactate-fermenting, gas-producing Clostridium spp. isolated from milk. Int. J. Food Microbiol. 43:173-183. https://doi .org/10.1016/s0168-1605(98)00108-1.

Isolini, D. 1990. Selektivmedien zum Nachweis von obligat und fakultativ heterofermentativen Laktobazillen. Schweiz. Milchwirtsch. Forsch. 19:57-59.

Jakob, E. 2005. Buttersäureblähung-noch immer aktuell. ALP Forum No. 20 d. Agroscope, Liebefeld-Posieux, Switzerland.

Klijn, N., F. F. J. Nieuwenhof, J. D. Hoolwerf, C. B. Van der Waals, and A. H. Weerkamp. 1995. Identification of Clostridium tyrobutyricum as the causative agent of late blowing in cheese by speciesspecific PCR amplification. Appl. Environ. Microbiol. 61:29192924

Komori, K., Y. Ohkubo, N. Katano, and H. Motoshima. 2019. One year investigation of the prevalence and diversity of clostridial spores in raw milk from the Tokachi area of Hokkaido. Anim. Sci. J. 90:135-139. https://doi.org/10.1111/asj.13135.

Le Bourhis, A.-G., J. Doré, J.-P. Carlier, J.-F. Chamba, M.-R. Popoff, and J.-L. Tholozan. 2007. Contribution of $C$. beijerinckii and $C$. sporogenes in association with C. tyrobutyricum to the butyric fermentation in Emmental type cheese. Int. J. Food Microbiol. 113:154-163. https://doi.org/10.1016/j.ijfoodmicro.2006.06.027.

Ledenbach, L. H., and R. T. Marshall. 2009. Microbiological spoilage of dairy products. Pages 41-67 in Compendium of the Microbiological Spoilage of Foods and Beverages. M. P. D. W. H. Sperber, ed. Springer Science and Business Media, New York, NY.

Martin, N. H., D. J. Kent, R. L. Evanowski, T. J. Zuber Hrobuchak, and M. Wiedmann. 2019. Bacterial spore levels in bulk tank raw milk are influenced by environmental and cow hygiene factors. J. Dairy Sci. 102:9689-9701. https://doi.org/10.3168/jds.2019-16304.

Matteuzzi, D., L. D. Trovatelli, B. Biavati, and G. Zani. 1977. Clostridia from Grana cheese. J. Appl. Bacteriol. 43:375-382. https:// doi.org/10.1111/j.1365-2672.1977.tb00763.x.

Sheehan, J. J. 2011. Cheese-Avoidance of gas blowing. Pages 661-666 in Encyclopedia of Dairy Sciences. Vol. 2. Academic Press, San Diego, CA.

Stadhouders, J. 1990. Prevention of butyric acid fermentation by the use of nitrate. Pages 40-46 in Methods of Detection and Prevention of Anaerobic Spore Formers in Relation to the Quality of Cheese. Vol. 251. Bulletin of the International Dairy Federation, Brussels, Belgium.

Turchi, B., S. Pero, B. Torracca, F. Fratini, S. Mancini, A. Galiero, F. Pedonese, R. Nuvoloni, and D. Cerri. 2016. Occurrence of Clostridium spp. in ewe's milk: Enumeration and identification of isolates. Dairy Sci. Technol. 96:693-701. https://doi.org/10.1007/s13594 -016-0298-x.

Turgay, M., W. Schaeren, H. U. Graber, E. Wagner, R. Amrein, U. Bütikofer, and D. Wechsler. 2018. A field study investigating the effectiveness of vat milk controls by qPCR for the prevention of undesired propionic acid fermentation in Sbrinz PDO cheese. Int. Dairy J. 77:80-88. https://doi.org/10.1016/j.idairyj.2017.06.008.

Vissers, M. M., F. Driehuis, M. C. Te Giffel, P. De Jong, and J. M. Lankveld. 2007. Minimizing the level of butyric acid bacteria spores in farm tank milk. J. Dairy Sci. 90:3278-3285. https://doi .org/10.3168/jds.2006-798.

ZAMG. 2018. Viertwärmster Sommer der Messgeschichte. Zentralanstalt für Meteorologie und Geodynamik. Accessed Jun. 7, 2019 https://www.zamg.ac.at/cms/de/klima/news/viertwaermster -sommer-der-messgeschichte.

\section{ORCIDS}

J. Burtscher (1) https://orcid.org/0000-0002-7452-0426

K. J. Domig @ https://orcid.org/0000-0003-1090-4284 